\title{
Correction to: Vestronidase Alfa: A Review in Mucopolysaccharidosis VII
}

\author{
Emma H. McCafferty ${ }^{1}$. Lesley J. Scott ${ }^{1}$
}

Published online: 16 April 2019

(c) Springer Nature 2019

\section{Correction to: BioDrugs (2019) 33:233-240 https://doi.org/10.1007/s40259-019-00344-7}

The article Vestronidase Alfa: A Review in Mucopolysaccharidosis VII, written by Emma H. McCafferty and Lesley J. Scott, was originally published Online First without open access. After publication in volume 33, issue 2, pages 233-240 Ultragenyx Pharmaceutical Inc., requested that the article be Open Choice to make the article an open access publication. Post-publication open access was funded by Ultragenyx Pharmaceutical Inc.

This article is licensed under a Creative Commons Attribution-NonCommercial 4.0 International License, which permits any non-commercial use, sharing, adaptation, distribution and reproduction in any medium or format, as long as you give appropriate credit to the original author(s) and the source, provide a link to the Creative Commons licence, and indicate if changes were made. The images or other third party material in this article are included in the article's Creative Commons licence, unless indicated otherwise in a credit line to the material. If material is not included in the article's Creative Commons licence and your intended use is not permitted by statutory regulation or exceeds the permitted use, you will need to obtain permission directly from the copyright holder. To view a copy of this licence, visit http:// creativecommons.org/licenses/by-nc/4.0/.

The original article has been corrected.

Open Access This article is licensed under a Creative Commons Attribution-NonCommercial 4.0 International License, which permits any non-commercial use, sharing, adaptation, distribution and reproduction in any medium or format, as long as you give appropriate credit to the original author(s) and the source, provide a link to the Creative Commons licence, and indicate if changes were made. The images or other third party material in this article are included in the article's Creative Commons licence, unless indicated otherwise in a credit line to the material. If material is not included in the article's Creative Commons licence and your intended use is not permitted by statutory regulation or exceeds the permitted use, you will need to obtain permission directly from the copyright holder. To view a copy of this licence, visit http://creativecommons.org/licenses/by-nc/4.0/.

The original article can be found online at https://doi.org/10.1007/ s40259-019-00344-7.

Lesley J. Scott

demail@springer.com

1 Springer, Private Bag 65901, Mairangi Bay, Auckland 0754, New Zealand 